\title{
Addition to the fauna of synanthropic woodlice in the south of Western Siberia, Russia (Isopoda: Oniscidea)
}

\author{
Аополнение к фауне синантропных мокрищ юга Западной \\ Сибири, Россия (Isopoda: Oniscidea)
}

\author{
P.S. Nefediev ${ }^{1,2}$, K.B. Gongalsky ${ }^{3}$, Yu.M. Lebedev ${ }^{4}$, D.A. Efimov ${ }^{5}$ \\ П.С. Нефедьев ${ }^{1,2}$, К.Б. Гонгальский ${ }^{3}$, Ю.М. Аебедев ${ }^{4}$, А.А. Ефимов
}

\footnotetext{
${ }^{1}$ Altai State University, Lenin Avenue, 61, Barnaul 656049 Russia. E-mail: p.nefediev@mail.ru

${ }^{2}$ Tomsk State University, Biological Institute, Lenin Avenue, 36, Tomsk 634050 Russia.

${ }^{3}$ A.N. Severtsov Institute for Problems of Ecology and Evolution, Russian Academy of Sciences, Leninsky prospect 33, Moscow 119071 Russia. E-mail: gongalsky@gmail.com

${ }^{4}$ M.V. Lomonosov Moscow State University, Leninskie Gory, 1, Moscow 119991 Russia. E-mail: lebedev ym@yahoo.com

${ }^{5}$ Kemerovo State University, Krasnaya Street, 6, Kemerovo 650043 Russia. E-mail: efim_d@mail.ru

${ }^{1}$ Алтайский государственный университет, проспект Ленина, 61, Барнаул 656049 Россия.

${ }^{2}$ Томский государственный университет, Биологический институт, проспект Ленина, 36, Томск 634050 Россия.

${ }^{3}$ Институт проблем экологии и эволюции им. А.Н. Северцова РАН, Ленинский проспект, 33, Москва 119071 Россия.

${ }^{4}$ Московский государственный университет им. М.В. Ломоносова, Ленинские Горы, 1, Москва 119991 Россия.

${ }^{5}$ Кемеровский государственный университет, ул. Красная, 6, Кемерово 650043 Россия.
}

KEY WORDS: terrestrial isopods, woodlice, Porcellio scaber, Porcellionides pruinosus, Protracheoniscus major, synanthropic, faunistics, invasive species, Siberia.

КЛЮЧЕВЫЕ СЛОВА: наземные изоподы, мокрицы, Porcellio scaber, Porcellionides pruinosus, Protracheoniscus major, синантроп, фаунистика, инвазивные виды, Сибирь.

ABSTRACT. New records of woodlice from anthropogenic and semi-natural habitats of the south of W Siberia replenish the list by three more synanthropic species, and now it comprises at least 7 species from six genera and five families. The genus Protracheoniscus Verhoeff, 1917 and the species P. major (Dollfus, 1903) are reported from the Asian part of Russia for the first time. The following records are new to Siberia: Porcellio scaber Latreille, 1804; Porcellionides pruinosus (Brandt, 1833) and the genus Porcellionides Miers, 1877 to the south of W Siberia; Trachelipus rathkii (Brandt, 1833) to the Novosibirsk and Kemerovo areas, and the Republic of Altai. All new synanthropic woodlouse distributions in the region are mapped.

How to cite this article: Nefediev P.S., Gongalsky K.B., Lebedev Yu.M., Efimov D.A. 2018. Addition to the fauna of synanthropic woodlice in the south of Western Siberia, Russia (Isopoda: Oniscidea) // Arthropoda Selecta. Vol.27. No.1. P.33-36. doi: 10.15298/ arthsel. 27.1.04

РЕЗЮМЕ. Новые находки мокриц из антропогенных и полуестественных местообитаний юга Западной Сибири пополняют список антропохоров тремя видами-вселенцами, который насчитывает на сегодняшний день как минимум 7 видов из шести родов и пяти семейств. В азиатской части России впервые отмечены род Protracheoniscus Verhoeff, 1917 и вид P. major (Dollfus, 1903). Указанные ниже находки оказались новыми для Сибири: Porcellio scaber Latreille, 1804; Porcellionides pruinosus (Brandt, 1833) и род Porcellionides Miers, 1877 для юга Западной Сибири; Trachelipus rathkii (Brandt, $1833)$ для Новосибирской и Кемеровской областей и Республики Алтай. Даны карты с распространением всех новых находок синантропных видов мокриц в указанном регионе.

\section{Introduction}

Despite the recently appeared a few papers on southwestern Siberian terrestrial isopods, the woodlouse fauna of the region still remains very poorly studied. The only four woodlouse species have currently been known as synanthropic introductions to SW Siberia: Porcellio laevis Latreille, 1804, Cylisticus convexus (De Geer, 1778), Trachelipus rathkii (Brandt, 1833) and Trichoniscus pygmaeus Sars, 1898 [Khisametdinova et al., 2016]. There are a number of previously published ecological articles on soil macrofauna of the Kemerovo and Tyumen areas, where terrestrial isopods had been mentioned at the order level and considered as one of components in soil ecosystems [Eremeeva, 2002, 2004, 2006, 2011; Eremeeva et al., 2013, 2014; Sergeeva, 2010, 2016]. 


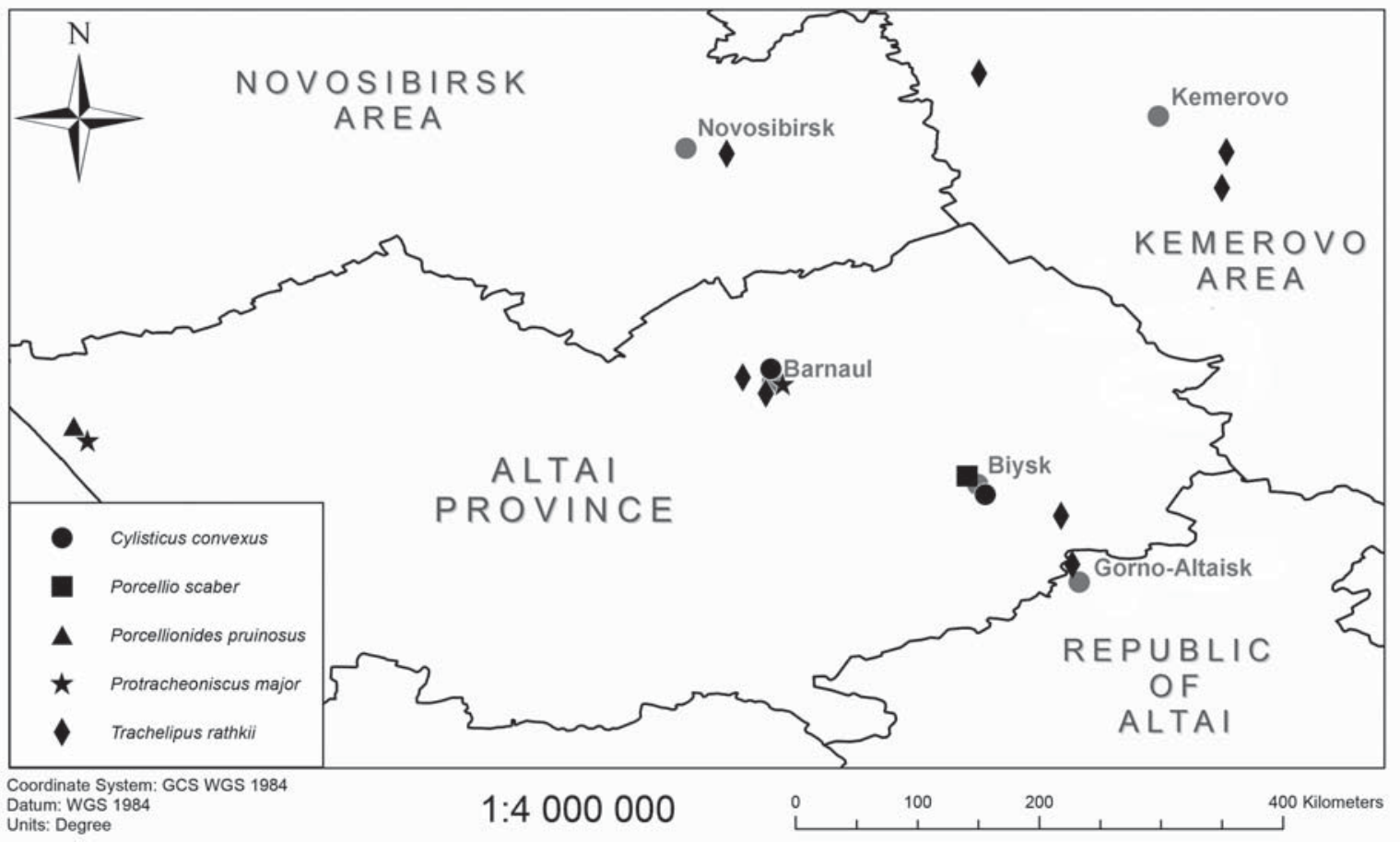

Map 1. New records of synanthropic woodlice in the south of Western Siberia. Карта 1. Новые находки синантропных мокриц на юге Западной Сибири.

The material treated herein has been deposited mainly in the collection of the Altai State University, Barnaul, Russia (ASU), partly retained in the collection of the Zoological Museum of the Lomonosov Moscow State University, Moscow, Russia (ZMUM), as indicated in the text. Literature references to the species concern southwestern Siberia only.

\section{Taxonomic part}

\section{ORDER ONISCIDEA}

\section{Family AGNARIDAE}

Protracheoniscus major (Dollfus, 1903) Map 1.

MATERIAL EXAMINED. $20^{7} 0^{7}, 2$ 오 (ZMUM Mc-1411), 3 $O^{\top} O^{2}, 5$ 우, 5 juv. (ASU), Russia, southwestern Siberia, Altai Province, Barnaul, Altai State University, $53.347405^{\circ} \mathrm{N}$, 83.775501 ${ }^{\circ} \mathrm{E}$, basement, 03-04.2016, leg. L.A. Durnikin; 1 ( (ASU), same Province, Barnaul, Skiing Lodge "Dinamo", 53.303271 ${ }^{\circ} \mathrm{N}$ $83.765472^{\circ} \mathrm{E}$, mixed forest, 22.07 .2010 , leg. I.S. Denisova; $1 \mathrm{O}$ (ASU), same Province, Barnaul, 53.356059 ${ }^{\circ} \mathrm{N}, 83.770351^{\circ} \mathrm{E}$, in side apartment, in bathroom, 17.06.2016, leg. V. Zaritovskaya, V. Novichikhina; $1 \sigma^{\text {T}}, 8$ 우 (ASU), same Province, Slavgorod District, Yarovoe, $52.923446^{\circ} \mathrm{N}, 78.569601^{\circ} \mathrm{E}$, plant debris near gardens, 20-27.07.2016, leg. D.A. Efimov; 1 (ASU), same Province, Barnaul, shopping center "Plaza", $53.330447^{\circ} \mathrm{N}, 83.782153^{\circ} \mathrm{E}$, 13.02.2017, leg. J.S. Nefedieva.

DISTRIBUTION. The species is widespread from SE Germany to Central Asia [Schmalfuss, 2003]. In Russia the species has previously been recorded in the southern part of European Russia [Kuznetsova, Gongalsky, 2012].

REMARKS. Both the genus Protracheoniscus Verhoeff, 1917, and the species P. major (Dollfus, 1903), are recorded in the Asian part of Russia for the first time.

\section{Family CYLISTICIDAE}

\section{Cylisticus convexus (De Geer, 1778)} Map 1.

Cylisticus convexus (De Geer, 1778): Khisametdinova et al., 2016: 53.

MATERIAL EXAMINED. 1 ๆ , 3 oq, 1 juv. (ASU), Russia, southwestern Siberia, Altai Province, Biysk, Centre of Hygiene and Epidemiology of the Altai Province, $52.536175^{\circ} \mathrm{N}, 85$. $212581^{\circ} \mathrm{E}$, Betula pendula stand, 16.06.2015, leg. P.S. Nefediev, J.S. Nefedieva; 1 q (ASU), same Province, Barnaul, Shukshin Street, $53.372176^{\circ} \mathrm{N}, 83.669328^{\circ} \mathrm{E}$, Betula pendula stand, above cellars, 29.09.2017; 5 우, 1 juv. (ASU), same Province, Barnaul, near Altai Province Sport School, $53.355274^{\circ} \mathrm{N}, 83.727085^{\circ} \mathrm{E}, \mathrm{Ul}$ mus and Betula pendula stand, above cellars, 3.11.2017, all leg. P.S. Nefediev.

DISTRIBUTION. Cylisticus convexus is widely distributed throughout Europe and Asia Minor, likewise introduced to northern Africa, both Americas and Australia [Schmalfuss, 2003]. In Russia it has been earlier reported from central, northeastern and southern parts of European Russia [Kuznetsova, Gongalsky, 2012], and also recently found introduced to a hothouse of the M.A. Lisavenko Research Institute for Horticulture of Siberia in the city Barnaul, Altai Province [Khisametdinova et al., 2016]. 
REMARKS. The above are the first formal records of this species from open grounds in semi-anthropogenic habitats in Siberia.

\section{Family TRACHELIPODIDAE}

\section{Trachelipus rathkii (Brandt, 1833) Map 1.}

Trachelipus rathkii (Brandt, 1833): Khisametdinova et al., 2016: 52.

MATERIAL EXAMINED. $20^{7} \sigma^{7}$ (ASU), Russia, southwestern Siberia, Altai Province, Barnaul, Novomikhailovka, 53. $349704^{\circ} \mathrm{N}, 83.477753^{\circ} \mathrm{E}$, open hand-made grounds, 1.05 .2016 , leg. G.N. Kuftina; $1 \sigma^{\text {T }}$ (ASU), same Province, Barnaul, Lake Pionerskoe, 14.06.2016, leg. E.V. Guskova; 1 (ASU), same Province, Krasnogorskoe District, $3 \mathrm{~km} \mathrm{~N}$ of Bystryanka, Acer and Alnus stands along Chuya Tract, $52.3275^{\circ} \mathrm{N}, 85.827222^{\circ} \mathrm{E}, 215 \mathrm{~m}$ a.s.1. 15.08.2016, leg. P.S. Nefediev, J.S. Nefedieva; $30^{7} \sigma^{7}, 4$ 우 (ASU), same Province, Barnaul, Solnechnaya Polyana, 53. $374928^{\circ} \mathrm{N}, 83.647527^{\circ} \mathrm{E}$, ruderal vegetation near buckwheat fields, 8.10.2017; 1 juv. (ASU), same Province, Barnaul, near Altai Province Sport School, $53.355274^{\circ} \mathrm{N}, 83.727085^{\circ} \mathrm{E}$, Ulmus and Betula pendula stand, above cellars, 3.11.2017, all leg. P.S. Nefediev; 2 $\sigma^{7} \sigma^{7}, 2$ 우 (ZMUM Mc-1412), 4 ○ $^{7} \sigma^{7}, 10$ 웅, 4 juv. (ASU), Russia, southwestern Siberia, Republic of Altai, Maima District, Gorno-Altaisk, $51.966873^{\circ} \mathrm{N}, 85.908893^{\circ} \mathrm{E}$, floodplain of Maima River, Salix on right bank, 22.06.2016, leg. J.S. Nefedieva; $1 \sigma^{\top}, 1$ o (ASU), Russia, southwestern Siberia, Novosibirsk Area, Novosibirsk District, valley of Krutikha River, near Geodezicheskaya Railway Station, $54^{\circ} 59^{\prime} 19^{\prime \prime} \mathrm{N}, 83^{\circ} 22^{\prime} 30^{\prime \prime} \mathrm{E}, 135 \mathrm{~m}$ a.s.l., anthropogenic rocky outcrops on roadside in Betula forest, 23.07.2016; 4 ind. (ZMUM Mc-1413), 26 ind. (ASU), same Area and District, valley of Inya River, right bank, "Izumrud" Gardening Partnership, $55^{\circ} 00^{\prime} 13^{\prime \prime} \mathrm{N}, 83^{\circ} 21^{\prime} 30^{\prime \prime} \mathrm{E}, 110 \mathrm{~m}$ a.s.l., open hand-made grounds, 23.07.2016; 49 ind. (ASU), same Area and District, valley of Inya River, right bank, $2 \mathrm{~km} \mathrm{SSW}$ of Plotnikovo, $55^{\circ} 00^{\prime} 43^{\prime \prime} \mathrm{N}, 83^{\circ}$ $22^{\prime} 33^{\prime \prime}$ E, $110 \mathrm{~m}$ a.s.l., small rocks and rocky outcrops at foot of slope, covered with Pinus sylvestris, Betula pendula and Populus tremula forest, on river bank, 23.07.2016, all leg. A.A. Fomichev; $10^{7}, 2$ 오 (ZMUM Mc-1414), Russia, southwestern Siberia, Kemerovo Area, Kemerovo District, Kriokovo, $55^{\circ} 31^{\prime} \mathrm{N}, 85^{\circ} 52^{\prime} \mathrm{E}$ 20.08.2016; $1 \mathrm{O}^{7}, 1$ (ASU), same locality, plant debris, 28.05.2017; 5 우 (ASU), same Area, Krapivinskii District, near Zelenogorskii, $55^{\circ} 01^{\prime} \mathrm{N}, 87^{\circ} 03^{\prime} \mathrm{E}$, on river bank, 9.07.2017; 8 우 (ASU), same Area and District, $8 \mathrm{~km} \mathrm{SSW}$ of Saltymakovo, Kemerovo State

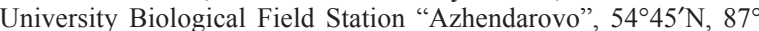
$01^{\prime}$ E, floodplain of Tom River, 28.07.2017, all leg. D.A. Efimov.

DISTRIBUTION. The species is distributed throughout most of Europe except for the Mediterranean, and also introduced to the Americas [Schmalfuss, 2003]. In Russia $T$. rathkii is widely distributed in northwestern and southern European Russia, and also it has been recently found in anthropogenic and semi-natural habitats in the Altai Province, Asian Russia [Khisametdinova et al., 2016].

REMARKS. This species has hitherto been recorded neither in the Novosibirsk and Kemerovo areas nor in the Republic of Altai, southwestern Siberia.

\section{Family PORCELLIONIDAE}

\section{Porcellio scaber Latreille, 1804 Map 1.}

MATERIAL EXAMINED. $1 \bigcirc^{7}, 2$ (ZMUM Mc-1415), 2 $\sigma^{7} \sigma^{7}, 4$ 우, 1 juv. (ASU), Russia, southwestern Siberia, Altai Province, Biysk, Centre of Hygiene and Epidemiology of the Altai Province, $52.536175^{\circ} \mathrm{N}, 85.212581^{\circ} \mathrm{E}$, Betula pendula stand, 16.06 . 2015, leg. P.S. Nefediev, J.S. Nefedieva.
DISTRIBUTION. This species is very widespread in Europe except its southeastern part, and also introduced to many localities of the world, e.g. Australia, Japan, etc. [Schmalfuss, 2003]. In Russia this species has previously been recorded in central and southern European Russia and the Russian Far East [Kuznetsova, Gongalsky, 2012].

REMARKS. The above is the first report of the species from Siberia.

\section{Porcellionides pruinosus (Brandt, 1833) Map 1.}

MATERIAL EXAMINED. 1 juv. (ZMUM Mc-1416), Russia, southwestern Siberia, Altai Province, Slavgorod District, Yarovoe, $52.923446^{\circ} \mathrm{N}, 78.569601^{\circ} \mathrm{E}$, plant debris near gardens, 20 27.07.2016, leg. D.A. Efimov.

DISTRIBUTION. Being Mediterranean in origin, this species is very widespread in Europe, as well as in Transcaucasia [Schmalfuss, 2003; Kuznetsova, Gongalsky, 2012]. In European Russia this species has previously been found introduced in central and southern parts of the country, and also known from eastern Siberia [Kuznetsova, Gongalsky, 2012; Khisametdinova et al., 2016].

REMARKS. Being synanthropically cosmopolitan this species had been predicted to occur in SW Siberia by Khisametdinova et al. [2016], now it is reported above for the first time.

\section{Conclusions}

At present, at least 7 species of terrestrial isopods from 6 genera and 5 families are known to occur in southwestern Siberia, Russia as synanthropic introductions. Both the genus Protracheoniscus Verhoeff, 1917, and the species $P$. major (Dollfus, 1903), are recorded in Asian Russia for the first time. Porcellio scaber Latreille, 1804 is formally new to the woodlouse fauna of Siberia, Porcellionides pruinosus (Brandt, 1833) and the genus Porcellionides Miers, 1877 are newly reported from the south of W Siberia, while Trachelipus rathkii (Brandt, 1833) has never been recorded in the Novosibirsk and Kemerovo areas, as well as in the Republic of Altai.

Acknowledgements. We are most thankful to I.H. Tuf (Olomouc, Czech Republic) for his valuable comments. Our deepest gratitude is extended to all collectors who donated us their material for study.

\section{References}

Eremeeva N.I. 2002. [Herpetobionts as indicators of cleanliness in a city environment] // Izvestiya YuFU. Tekhnicheskie nauki. No.6(29). Ekologiya 2002 - more i chelovek. P.145-148 [in Russian, with English summary].

Eremeeva N.I. 2004. [Eco-faunistic studies of herpetobionts in an urban territory] // Izvestiya YuFU. Tekhnicheskie nauki. No.5(40). Ekologiya 2004 - more i chelovek. P.194-197 [in Russian, with English summary].

Eremeeva N.I. 2006. [A role of city environmental factors in formation of invertebrate macrofauna] // Izvestiya YuFU. Tekhnicheskie nauki. No.12(67). P.106-110 [in Russian, with English summary]. 
Eremeeva N.I. 2011. [A formation of arthropod macrofauna in urban conditions] // Izvestiya YuFU. Tekhnicheskie nauki. No.9(122). P.186-191 [in Russian, with English summary].

Eremeeva N.I., Luzyanin S.L., Korchagina M.R., Blinova S.V., Efimov D.A., Savosin N.I., Sidorov D.A., Yakovleva S.N., Kuropyatnik K.N. 2013. [The herpetobiont structure on waste dumps of opencast coal mines] // Sovremennye problem nauki i obrazovaniya. No.6. Available at http://www.scienceeducation.ru/113-11058 (accessed 10 October 2017).

Eremeeva N.I., Luzyanin S.L., Korchagina M.R., Kuropyatnik K.N. 2014. [The structural changes of herpetobionts at early stages of reclamation of waste dumps of opencast coal mine] // Sovremennye problem nauki i obrazovaniya. No.6. Available at http:/ /www.science-education.ru/ru/article/view?id=16239 (accessed 10 October 2017).

Khisametdinova D.D., Nefediev P.S., Tuf I.H. 2016. New records of woodlice in the south of western Siberia, Russia (Isopoda: Oniscidea) // Invertebrate Zoology. Vol.13. No.1. P.51-55.
Kuznetsova D.M., Gongalsky K.B. 2012. Cartographic analysis of woodlice fauna of the former USSR // ZooKeys. Vol.176. P.111.

Schmalfuss H. 2003. World catalog of terrestrial isopods (Isopoda: Oniscidea) // Stuttgarter Beiträge zur Naturkunde. Serie A. Nr.654. 341 p.

Sergeeva E.V. 2010. [Population dynamics of soil-dwelling invertebrates in grassy communities from the southern taiga of Western Siberia] // Belgorod State University Scientific Bulletin. Natural sciences. No.9(80). Issue 11. P.65-72 [in Russian, with English summary].

Sergeeva E.V. 2016. [The trophic structure of soil macrofauna in the southern taiga communities of Western Siberia] // Belgorod State University Scientific Bulletin. Natural sciences. No.11(232). Issue 35. P.41-48 [in Russian, with English summary].

Responsible editor K.G. Mikhailov 